\title{
Evaluation of physicochemical parameters influencing bulking episodes in a municipal wastewater treatment plant
}

\author{
J. Bayo $^{1}$, J. M. Angosto ${ }^{1}$, J. Serrano-Aniorte ${ }^{1}$, J. A. Cascales- \\ Pujalte $^{1}$, C. Fernández-López ${ }^{1} \&$ J. López-Castellanos ${ }^{2}$ \\ ${ }^{1}$ Department of Chemical and Environmental Engineering, \\ Technical University of Cartagena, Spain \\ ${ }^{2}$ Municipal Wastewater Treatment Plant, Cartagena, Spain
}

\begin{abstract}
A study of physicochemical parameters in a municipal wastewater treatment plant was undertaken to consider the presence of bulking phenomena by means of statistical and logistic regression analyses. There appears to be an important effect on activated sludge settleability that can be related to the temperature of wastewater. Besides, there were significant differences between the percentage of nitrogen removal from the secondary treatment with the season. The SVI increased with conductivity, meanwhile $\mathrm{BOD}_{5}$ removal decreased with this parameter. The development of logistic regression models identified two statistically significant variables that appeared to be important to the contribution of a higher SVI: season and $\mathrm{pH}$.
\end{abstract}

Keywords: wastewater, physicochemical parameters, bulking, modelling.

\section{Introduction}

Wastewater treatment plants are complex systems, with different physicochemical and biological phenomena taking place simultaneously. Wastewater collected from municipalities and communities must ultimately be returned to receiving waters or to the land [1]. Besides, due to the limited water resource, a great attention is being paid into reclamation and reuse of wastewater from municipalities mainly for irrigation [2]. In all cases, water quality standards are becoming more and more stringent. 
Prior to the industrial development, most municipal wastewater was generated from domestic sources. Nowadays, an increasing amount of industrial wastewater is being discharged to municipal collection systems, specially in Spain. In the Region of Murcia, situated at Southeast of Spain, the industrial wastewater disposal grew up to $50 \%$ of all wastewater discharged in municipal collectors.

Many different secondary wastewater treatment processes exist, although the most commonly used technology for municipal wastewater treatment is the activated-sludge process system. This system was first introduced in England in 1914 as a municipal wastewater treatment technology [1]. It consists of two stages: a biochemical step, taking place in an aeration tank, and a physical stage in a secondary clarifier. Bulking sludge is a common problem in activated sludge process. Despite much research, bulking sludge seems to be a continuous problem in operating wastewater treatment plants [3].

Statistical models to predict the behaviour of a dependent variable, studying the factors or variables involved in it have been deeply used. During the 1960s, the logistic regression model was proposed as a tool for the analysis of characteristics which influence different processes. In this sense, these statistical models have been used for marketing [4], the likely occurrence or distribution of species in habitat models [5], or the formation of trihalomethanes in water chlorination [6].

Logistic regression models provide a good way to examine how various factors influence a binary outcome. The set of independent variables can be continuous, categorical or dichotomous.

The focus of this paper was to investigate the contribution of different physicochemical parameters to bulking episodes, and to develop logistic regression models to predict this phenomenon in a municipal wastewater treatment plant (WWTP). For this purpose, a threshold SVI value of $150 \mathrm{ml} / \mathrm{g}$ and data from 2003 with different physicochemical factors were used for the prediction. The plant was constructed during 1970s for the treatment of industrial and municipal wastewater in the city of Cartagena, by means of stabilization ponds. From 2001, the process was changed into a conventional system, with a primary treatment and two activated-sludge reactors (A and $\mathrm{B})$.

\section{Materials and methods}

\subsection{Measured variables}

The influent and the effluent wastewater to the aerobic activated-sludge process was daily sampled for $\mathrm{pH}$, conductivity, and flow rate measurements. The other parameters were normally measured twice a week, except for $\mathrm{COD}$ and $\mathrm{BOD}_{5}$, which were analysed each four days. Only total nitrogen, ammonium and nitrate concentrations were measured once a week.

Biomass concentrations (MLSS) were determined by filtering the wastewater samples through $0.45 \mu \mathrm{m}$ Millipore filter and drying in an oven at $105^{\circ} \mathrm{C}$ until constant weight. 
Most other parameters were determined in conformity with the "Standard Methods for the Examination of Water and Wastewater" [7]. In order to study the influence of temperature on different variables, data were subdivided into four groups: (1) $\leq 15.0^{\circ} \mathrm{C}$; (2) between 15.1 and $20.0^{\circ} \mathrm{C}$; (3) between 20.1 and $24.0^{\circ} \mathrm{C}$; and $(4) \geq 24.1^{\circ} \mathrm{C}$. Conductivity values were also classified according to seven groups: (1) $\leq 500 \mu \mathrm{S} / \mathrm{cm}$; (2) between 501 and $1,000 \mu \mathrm{S} / \mathrm{cm}$; (3) between 1,001 and 1,500 $\mu \mathrm{S} / \mathrm{cm}$; (4) between 1,501 and 2,000 $\mu \mathrm{S} / \mathrm{cm}$; (5) between 2,001 and 2,500 $\mu \mathrm{S} / \mathrm{cm}$; (6) between 2,501 and 3,000 $\mu \mathrm{S} / \mathrm{cm}$; and (7) $\geq 3,001 \mu \mathrm{S} / \mathrm{cm}$.

Statistical analysis was carried out using Statistical Package for the Social Sciences (SPSS for Windows 11.0). Bivariate associations between different variables measured in the WWTP were calculated using a one-way analysis of variance (ANOVA) test, with 95\% confidence interval.

\subsection{Models developing, variables definition and coding}

Logistic regression models are generally suitable where a dichotomous dependent variable exists, although they can also be used with a polytomous dependent variable. With this procedure, the coefficients of a probabilistic model can be estimated, involving a set of independent variables that best predict the value of a dependent variable [4].

SPSS for Windows 11.0 has been used for the developing of these logistic regression models. Forward:Wald option from this software was used to enter a variable on each step, always selecting that one with the highest score within the variables not included in the equation of the previous step. A significance level $95 \%(\alpha=0.05)$ was chosen for this option. At the same time, variables previously included for the model could be eliminated with a Wald statistic higher than 0.01 (99\% significance level).

The sludge volume index (SVI) in the WWTP was considered as the outcome variable, codified as: (1) SVI $\leq 150 \mathrm{ml} / \mathrm{g}$, and (2) SVI $>150 \mathrm{ml} / \mathrm{g}$. The cut-off value implemented in the model was 0.5 , which means that any predicted result over this threshold value will be included in the second group.

The variables included in the model were:

Conductivity (CONDUC). Classified into 7 levels previously described.

Temperature (TEMP). Divided into 4 four groups previously indicated.

Season (SEASON). (1) Winter, (2) Spring, (3) Summer, and (4) Autumn.

Settleable Solids (SETS). Classified into 2 groups, according to the mean value of the distribution: $(1) \leq 0.60 \mathrm{ml} / 1$, and $(2)>0.60 \mathrm{ml} / \mathrm{l}$.

Total Solids (TS). Data were classified into 2 levels, according to the mean value: (1) $\leq 2,122 \mathrm{mg} / \mathrm{l}$, and (2) $>2,122 \mathrm{mg} / \mathrm{l}$.

Chemical Oxygen Demand (COD). Also divided according the mean value of the distribution: (1) $\leq 817 \mathrm{mg} / \mathrm{l}$, and (2) $>817 \mathrm{mg} / \mathrm{l}$.

Biochemical Oxygen Demand (BOD). Also with 2 values: (1) $\leq 327 \mathrm{mg} / \mathrm{l}$, and (2) $>327 \mathrm{mg} / \mathrm{l}$.

$p H(P H)$. (1) $\leq 7.5$, and $(2)>7.5$. 


\section{Results and discussion}

\subsection{General observations}

As a previous step for the development of logistic regression models, the relationships between different variables were determined. The variables displaying statistically significant differences for settling characteristics, evaluated by using SVI values, were used to develop regression logistic models. Physicochemical factors considered in the study, but without significant importance on SVI values, were not taken into account for these logistic models.

The biological treatment was designed for an $\mathrm{BOD}_{5}$ influent of $252 \mathrm{mg} / \mathrm{l}$. The mean value of this parameter after the preliminary and primary treatments was $327 \mathrm{mg} / \mathrm{l}$, this is a $30 \%$ higher than the designed value. The lowest $\mathrm{BOD}_{5}$ influent value was $100 \mathrm{mg} / \mathrm{l}$ and corresponded to July 29th, coinciding with the beginning of Summer holidays. The maximum value was $500 \mathrm{mg} / \mathrm{l}$ for the $18 \mathrm{th}$ of March.

The designed average value for the flow rate was $34,992 \mathrm{~m}^{3} /$ day, a $34 \%$ over the mean flow rate measured $\left(26,077 \mathrm{~m}^{3} /\right.$ day). The maximum value corresponded to August $19^{\text {th }}$, with $37,710 \mathrm{~m}^{3} /$ day. This abnormal value should be assigned to the industrial activity, because a reduction of population in our city during summer time. There were no significant differences between the parameters measured in both activated-sludge reactors (A and B). These were: pH $(F=0.277, p=0.60)$; temperature $(F=0.034, p=0.85)$; conductivity $(F=$ $0.002, p=0.96)$, MLSS $(F=0.726, p=0.40)$, SVI $(F=0.014, p=0.91)$, and MLVSS $(F=0.588, p=0.44)$. For this reason, and for further considerations, both reactors comprising the activated-sludge process were treated as only one reactor, as presented in table 1 .

Table 1: $\quad$ Main statistic parameters for the aerobic activated-sludge system.

\begin{tabular}{|c|c|c|c|c|c|c|}
\hline Parameters & $\begin{array}{c}\text { No. } \\
\text { samples }\end{array}$ & Mean & Median & S.D. & Minimum & Maximum \\
\hline $\mathrm{pH}$ & 373 & 7.24 & 7.24 & 0.21 & 6.70 & 7.84 \\
\hline $\mathrm{T}\left({ }^{\circ} \mathrm{C}\right)$ & 373 & 22.2 & 22.7 & 3.8 & 12.1 & 28.2 \\
\hline $\begin{array}{c}\text { Conduct. } \\
(\mu \mathrm{S} / \mathrm{cm})\end{array}$ & 373 & 2,407 & 2,410 & 631 & 720 & 5,110 \\
\hline $\begin{array}{c}\mathrm{MLSS} \\
(\mathrm{mg} / \mathrm{l})\end{array}$ & 373 & 3,041 & 2,840 & 1,256 & 920 & 9,600 \\
\hline $\begin{array}{c}\text { MLVSS } \\
(\mathrm{mg} / \mathrm{l})\end{array}$ & 371 & 2,360 & 2,238 & 956 & 520 & 7,162 \\
\hline SVI & 369 & 118 & 86 & 79 & 30 & 451 \\
\hline
\end{tabular}

The mean value for MLVSS was 2,360 mg/l, representing 78\% of MLSS, this is $3,041 \mathrm{mg} / \mathrm{l}$. This mean value coincides with that value proposed for the WWTP design $(3,020 \mathrm{mg} / \mathrm{l})$, and it is the typical design parameter for the activated-sludge process called "conventional plug flow" [1]. 
Different figures have been reported for MLSS and MLVSS by other authors on the performance of activated-sludge reactors. Barr et al. [8] found a mean value of $1,675 \pm 191 \mathrm{mg} / \mathrm{l}$ for MLVSS on activated-sludge reactors treating kraft pulping effluent. Wang et al. [9] have reported a MLSS of 7,800 mg/L in an aerobic granular sludge cultivated in a sequencing batch reactor. A statistically significant improvement in sludge settleability was observed from $\mathrm{pH} \leq 7.5$ to $\mathrm{pH}$ $>7.5$, with SVI average values of $122 \pm 82 \mathrm{ml} / \mathrm{g}$ and $83 \pm 35 \mathrm{ml} / \mathrm{g}$, respectively $(F=3.96, p<0.05)$, as presented in fig. 1 . The effects of $\mathrm{pH}$ in sludge settleability has been observed by different authors, specially focused on the dewaterability and settleability of activated sludges. Bernard and Gray [10] reported a significant improvement in activated sludge dewaterability at $\mathrm{pH}$ between 7 and 8 , applied to the aerobic digestion of pharmaceutical and municipal wastewater sludges. This fact has also been reported by Neyens et al. [11] for the dewaterability of waste activated sludges, at a temperature of $100^{\circ} \mathrm{C}$ and $\mathrm{pH} 10$.

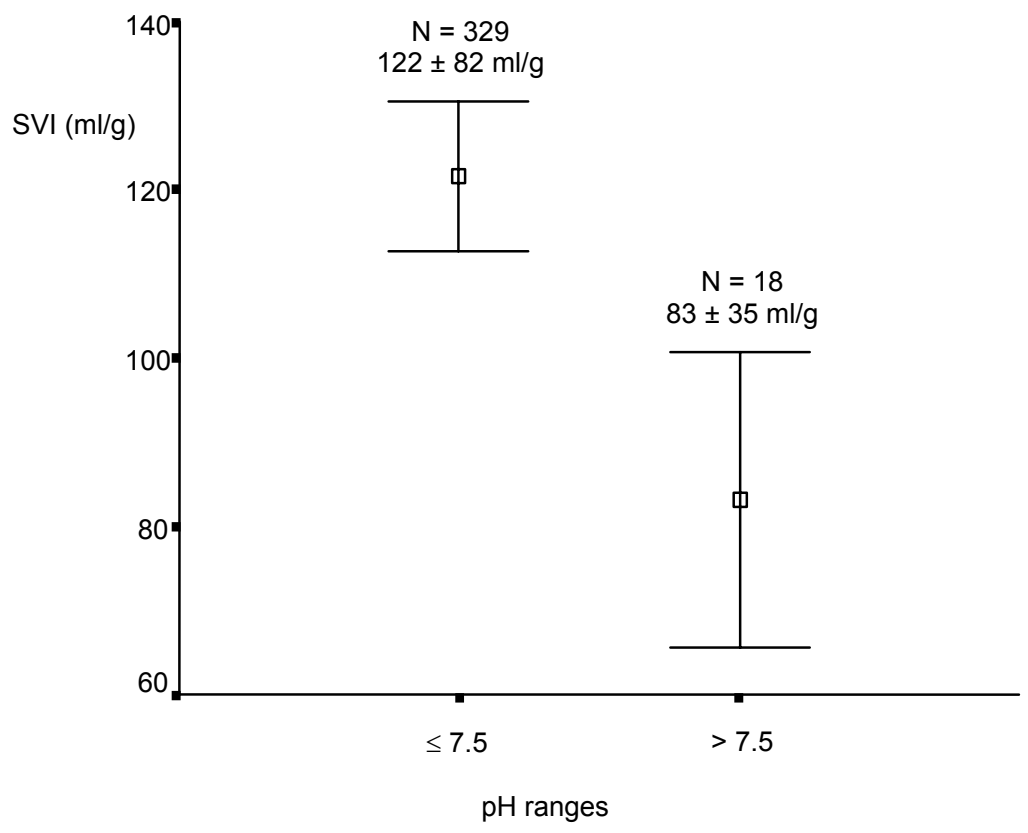

Figure 1: $\quad$ One-way ANOVA plot for sludge volume index by ranges of $\mathrm{pH}$.

The effects of temperature oscillations on aerobic bioreactor were evaluated with respect to the settling characteristics as measured by the SVI values, fig. 2 . There appears to be an important effect on activated sludge settleability that can be related to the temperature of wastewater, as statistically significant differences $(F=47.23, p<0.001)$ could be observed for the four ranges of temperature.

The temperature dependence of biological process has proved to be an important factor, influencing both the metabolic activities of microorganisms and sludge settleability [12]. Sürücü and Cetin [13] found a decrease in 
compressibility of sludges when temperature was increased from 15 up tp $25^{\circ} \mathrm{C}$ in a laboratory-scale semi-continuous reactor. However, above $25^{\circ} \mathrm{C}$ the sludges became more compressible. Krishna and Van Loosdrecht [14] reported a continuous decrease in sludge settleability, expressed as SVI increase, with increasing temperature, ranging from $110 \mathrm{ml} / \mathrm{g}$ for $15^{\circ} \mathrm{C}$ to $200 \mathrm{ml} / \mathrm{g}$ for $25^{\circ} \mathrm{C}$, in a sequencing batch reactor. As suggested by Tripathi and Grant Allen [15], these changes can be due to dispersed growth of pinpoint flocs. These decreased sludge settling characteristics with temperature are also in agreement with those reported by Morgan-Sagastume and Grant Allen [16] for a kraft pulp and paper mill effluent.

In common with previous reports, there was a strong correlation between the MLSS and MLVSS average concentrations in the reactor by ranges of temperatures, as presented in table 2. There was a regular increase of both parameters when the temperature increases: from 2,172 \pm 614 and $1,610 \pm 519 \mathrm{mg} / \mathrm{l}$ for $15.0^{\circ} \mathrm{C}$, up to $3,813 \pm 1,729$ and $2,969 \pm 1,274 \mathrm{mg} / \mathrm{l}$ for $24.0^{\circ} \mathrm{C}$, for MLSS and MLVSS respectively.

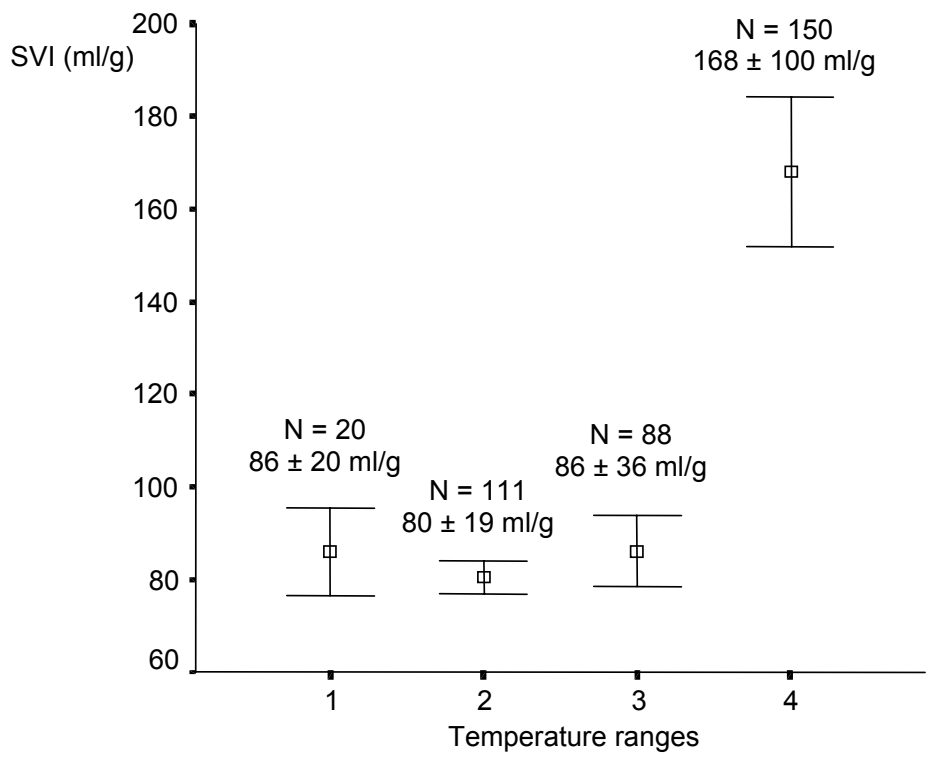

Figure 2: One-way ANOVA plot for sludge volume index by ranges of temperature.

$\mathrm{BOD}_{5}$ removal efficiency slightly increased from $89.08 \%$ to $95.53 \%$ when temperature increased from less than $15^{\circ} \mathrm{C}$ up to $24^{\circ} \mathrm{C}(F=4.60, p<0.01)$. This fact has been pointed out by several authors, because of an increase in biological activity with temperature. Steer et al. [17] have showed a decrease in $\mathrm{BOD}_{5}$ 
reduction during Winter time of about $10 \%$ when compared with other seasons, in a single-family constructed wetland system.

Table 2: One-way ANOVA test for MLSS and MLVSS values by temperature ranges.

\begin{tabular}{|l|c|c|c|c|}
\hline $\begin{array}{c}\text { Temperature } \\
\text { ranges }\end{array}$ & $\begin{array}{c}\text { MLSS } \\
(\mathrm{n})\end{array}$ & Mean \pm S.D. (mg/l) & $\begin{array}{c}\text { MLVS } \\
\mathrm{S}(\mathrm{n})\end{array}$ & Mean \pm S.D. (mg/l) \\
\hline & & $F=20.33, p<0.001$ & & $F=22.96, p<0.001$ \\
\hline $1\left(\leq 15.0^{\circ} \mathrm{C}\right)$ & 20 & $2,172 \pm 614$ & 18 & $1,610 \pm 519$ \\
\hline $\begin{array}{l}2(15.1- \\
\left.20.0^{\circ} \mathrm{C}\right)\end{array}$ & 111 & $2,673 \pm 1,019$ & 111 & $2,052 \pm 808$ \\
\hline $3\left(20.1-24.0^{\circ}\right)$ & 88 & $3,813 \pm 1,729$ & 88 & $2,969 \pm 1,274$ \\
\hline $4\left(\geq 24.0^{\circ} \mathrm{C}\right)$ & 154 & $2,978 \pm 895$ & 154 & $2,323 \pm 664$ \\
\hline
\end{tabular}

In our study, COD reduction efficiency showed to increase from Winter to Summer $(F=3.22, p<0.05)$, with average values of $89.35 \%$ and $91.79 \%$, respetively. This result is coincident with that reported by Tadesse et al. [18] in the treatment of tannery effluent with a pilot-scale advanced integrated wastewater pond system.

In agreement with previous studies, there were significant differences between the percentage of nitrogen removal from the secondary treatment with the season $(F=5.72, p<0.001)$, being higher for Summer $(56.34 \%)$ than for Winter (33.07\%). In this sense, Zimmo et al. [19] have reported a significant nitrogen removal rate during warm periods in wastewater stabilisation ponds. The same effect have been indicated by Jing and Lin [20] in a pilot-scale constructed wetland. These authors reported an increase in the volumetric removal rate constant when the mean water temperatures ranged between 18 and $31^{\circ} \mathrm{C}$ in the wetland system, indicating that the removal efficiency of nitrogen increased with temperature. According to these authors, this variation is mainly due to nitrification processes.

Sludge volume index increased with conductivity, from 62 to $270 \mathrm{ml} / \mathrm{g}$ when the conductivity varied between the ranges (2) and (7), this is: 501-1,000 to $\geq 3,001 \mu \mathrm{S} / \mathrm{cm}(F=46.06, p<0.001)$. As previously reported by Uygur and Kargi [21], this SVI increasing with conductivity could be explained as a result of plasmolysis of organisms at high salt contents. The death of microorganisms resulted in high SVI, indicative of settlement problems.

According to these results, the $\mathrm{BOD}_{5}$ removal decreased with conductivity, with statistically significant differences $(F=2.56, p<0.05)$. The lowest average value for $\mathrm{BOD}_{5}$ removal $(91.6 \%)$ was for the highest range of conductivity $(\geq 3,001 \mu \mathrm{S} / \mathrm{cm})$. On the contrary, the maximum efficiency for $\mathrm{BOD}_{5}$ removal $(96.2 \%)$ was for the lowest range of conductivity $(501-1,000 \mu \mathrm{S} / \mathrm{cm})$.

In agreement with previous studies, the same tendency appeared with COD removal and conductivity $(F=2.77, p<0.05)$, with a maximum value of COD removal $(92.3 \%)$ for the range (4) of conductivity, and a minimum average value $(88.9 \%)$ for a higher range of conductivity (between 2,501-3,000 $\mu \mathrm{S} / \mathrm{cm}$ ). An et al. [22] have reported a similar relationship behaviour between both parameters 
in the photocatalytic degradation of organic pollutans, with a significant decrease of COD removal efficiency while increasing in the conductivity of solution. Mass loading varied with the SVI, decreasing from $0.22 \mathrm{~kg} \mathrm{BOD} / / \mathrm{kg} \mathrm{MLVSS}$ for a SVI between $0-80 \mathrm{ml} / \mathrm{g}$, down to $0.17 \mathrm{~kg} \mathrm{BOD} / \mathrm{kg}$ MLVSS for a SVI higher than $150 \mathrm{ml} / \mathrm{g}(F=3.97 ; p<0.02)$. This fact was taken into account for further statistic analyses.

Finally, the average value for food:microorganisms (F/M) ratio was $0.17 \mathrm{~kg}$ $\mathrm{BOD}_{5} / \mathrm{kg}$ MLVSS. This parameter showed to decrease with the SVI, from 0.20 $\mathrm{kg} \mathrm{BOD} / \mathrm{kg} \mathrm{MLVSS} \mathrm{for} \mathrm{a} \mathrm{SVI} \mathrm{between} \mathrm{0-80} \mathrm{ml} / \mathrm{g}$, down to $0.14 \mathrm{~kg} \mathrm{BOD} / \mathrm{kg}$ MLVSS for a SVI higher than $150 \mathrm{ml} / \mathrm{g}(F=3.63 ; p<0.05)$.

\subsection{Logistic regression models}

Two logistic regression models were delivered by SPSS. The equation for model 1 was:

$\log$ odds $(S V I)=-2.51-8.64 * \operatorname{SEASON}(1)-8.64 * \operatorname{SEASON}(2)+3.66 * \operatorname{SEASON}(3)$ and for model 2 :

$$
\begin{aligned}
\log \text { odds }(S V I) & =-16.14-9.72 * \operatorname{SEASON}(1)-9.72 * \operatorname{SEASON}(2)+ \\
& +4.68 * \operatorname{SEASON}(3)+13.65 * P H(1)
\end{aligned}
$$

The first model included only one significant variable: $S E A S O N$. The positive $B$ coefficient for $S E A S O N(3)$ indicates that Summer season acts as a risk condition for SVI values over the arithmetic mean, this is $150 \mathrm{ml} / \mathrm{g}$, meanwhile the other seasons, with negative $B$ values or odds ratio fewer than 1 , would act as protective factors. These results are in agreement with the bivariate association previously described between SVI and temperature, indicating a higher probability to find SVI values over the mean during the hot season. The accuracy of this first model, defined as the percent of sample correctly predicted, was 93.3\%. The Forward:Wald option used for the development of logistic models gave a new model. The second significant variable selected for inclusion was $P H$, with a $B$ value of 13.65 . This high positive value indicates an important dependence of SVI values over the mean according to a lower $\mathrm{pH}$ of water $(\leq 7.5)$. It can be observed that, for this second model, the $B$ value for the hot season $[S E A S O N(3)]$ slightly increased up to 4.68, indicating a higher dependence. When $P H$ variable was included in the model, the accuracy grew up to $96.7 \%$. According to this second model, the risk estimation during the Summer period with a $\mathrm{pH}$ value of water $\leq 7.5$, would be 0.8994 , however, the probability of SVI over the mean value during the Summer period when $\mathrm{pH}$ of water is higher than 7.5 , descended up to $0.1054 \cdot \mathrm{E}^{-4}$. The specificity, defined as the number of samples with a SVI value equal or lower than the arithmetic mean correctly predicted by each model, grow from $94 \%$ for model 1 up to $98 \%$ for model 2. This improvement indicated a decrease in the false positive fraction down to $2 \%$ for model 2 . The specifity or true positive fraction was the same for both models: $90 \%$. Although the dicrimination ability was the same for both models, model 2 with $\mathrm{pH}$ variable, gave a better ability to predict the true negative fraction or specificity. 


\section{Conclusions}

The contribution of physicochemical parameters affecting the presence of bulking episodes in a municipal WWTP was investigated. As previously reported by different authors, an improvement in sludge settleability was observed for $\mathrm{pH}>7.5$ and lower temperatures $\left(<24.0^{\circ} \mathrm{C}\right)$. The study also showed an increase in $\mathrm{BOD}_{5}$ and nitrogen removal efficiency with increasing temperature. The SVI value increased with conductivity, explained as a result of plasmolysis or shrinkage of the microorganisms' protoplast. The rate of COD and $\mathrm{BOD}_{5}$ removals decreased with increasing conductivity, together with an increase of $\mathrm{BOD}_{5}$ elimination with mass loading. Settling characteristics of the sludge were also adversely affected by mass loading and food:microorganism ratio.

Logistic regression models identified two statistically significant variables that appeared to be important for higher SVI values, i.e., the summer season and a $\mathrm{pH}$ value under 7.5. The number of cases correctly predicted for the second model, containing both variables, was $98 \%$. Further surveys will allow us to validate the predictive performance of these models.

\section{Acknowledgement}

This study was supported by the Instituto Euromediterráneo de Hidrotecnia, Project number PI 0303 I.E.H.

\section{References}

[1] Tchobanoglous G, Burton F.L. \& Stensel HD., Introduction to process analysis and selection (Chapter 4). Wastewater Engineering: Treatment and Reuse, ed. G. Tchobanoglous, F.L. Burton \& H.D. Stensel, McGrawHill: Boston, pp. 215-310, 2003.

[2] Chen P.H., Leung K.C. \& Wang J.T., Investigation of a ponding irrigation system to recycle agricultural wastewater. Environment International, 26, pp. 63-68, 2000.

[3] Martins A.M.P., Pagilla K., Heijnen J.J. \& Van Loosdrecht M.C.M., Filamentous bulking sludge-a critical review. Water Research, 38, pp. 793-817, 2004.

[4] Mazzarol T., Critical success factors for internal education marketing. International Journal of Education Management, 12, pp. 163-175, 1998.

[5] Pearce J. \& Ferrier S., Evaluating the predictive performance of habitat models developed using logistic regression. Ecological Modelling, 133, pp. 225-245, 2000.

[6] Milot J., Rodríguez M.J. \& Sérodes J.B., Modeling the susceptibility of drinking water utilities to form high concentrations of trihalomethanes. Journal of Environmental Management, 60, pp. 155-171, 2000.

[7] APHA. Standard methods for the Examination of Water and Wastewater, 19 ed., American Public Health Association, Washington, DC.,1995. 
[8] Barr T.A., Taylor J.M. \& Duff S.J.B., Effect of HRT, SRT and temperature on the performance of activated sludge reactors treating bleached kraft mill effluent. Water Research, 30(4), pp. 799-810, 1996.

[9] Wang Q., Du G. \& Chen J. Aerobic granular sludge cultivated under the selective pressure as a driving force. Process Biochemical, 39, pp. 557-563, 2004.

[10] Bernard S. \& Gray N.F., Aerobic digestion of pharmaceutical and domestic wastewater sludge at ambient temperature. Water Research, 34(3), pp. 725-734, 2000.

[11] Neyens E., Baeyens J. \& Creemers C., Alkaline thermal sludge hydrolysis. Journal of Hazardous Materials, 97(1-3), pp. 295-314, 2003.

[12] Mulkerrins D., Dobson A.D.W. \& Colleran E, Parameters affecting biological phosphate removal from wastewaters. Environment International, 30, pp. 249-259, 2004.

[13] Sürücü G. \& Cetin F.D., Effect of temperature, $\mathrm{pH}$ and DO concentration on filterability and compressibility of activated sludge. Water Research, 23(11), pp. 1389-1395, 1998.

[14] Krishna C. \& Van Loosdrecht M.C.M., Effect of temperature on storage polymers and settleability of activated sludge. Water Research, 33, pp. 2374-2382, 1999.

[15] Tripathi C.S. \& Grant Allen D., Comparison of mesophilic and thermophilic aerobic biological treatment in sequencing batch reactors treating bleached kraft pulp mill effluent. Water Research, 33(3), pp. 836-846, 1999.

[16] Morgan-Sagastume F. \& Grant Allen D., Effects of temperature transient conditions on aerobic biological treatment of wastewater. Water Research, 37, pp.3590-3601, 2003.

[17] Steer D., Fraser L., Boddy J. \& Seibert B., Efficiency of small constructed wetlands for subsurface treatment of single-family domestic effluent. Ecological Engineering, 18, pp. 429-440, 2002.

[18] Tadesse I., Green F.B. \& Puhakka J.A., Seasonal and diurnal variations of temperature, $\mathrm{pH}$ and dissolved oxygen in advanced integrated wastewater pond system ${ }^{\circledR}$ treating tannery effluent. Water Research, 38, pp. 645-654, 2004.

[19] Zimmo O.R., Van der Steen N.P. \& Gijzen H.J., Nitrogen mass balance across pilot-scale algae and duckweed-based wastewater stabilization ponds. Water Research, 38(4), pp. 913-920, 2004.

[20] Jing S.R. \& Lin Y.F., Seasonal effect on ammonia nitrogen removal by constructed wetlands treating polluted river water in southern Taiwan. Environmental Pollution, 127, pp. 291-301, 2004.

[21] Uygur A. \& Kargi F., Salt inhibition on biological nutrient removal from saline wastewater in a sequencing batch reactor. Enzyme and Microbiological Technology, 34, pp. 313-318, 2004.

[22] An T., Xiong Y., Li G., Zha C. \& Zhu X., Synergetic effect in degradation of formic acid using a new photoelectrochemical reactor. Journal of Photochemical Photobiology A, 152, pp. 155-165, 2002. 